\title{
Effect of Nitrogen Levels and Gliricidia Sepium Alley Widths on Rice Based Agroforestry Systems
}

\author{
S Mondal ${ }^{* 1}$, M G Miah², N E Elahi, ${ }^{3}$ M A Saleque ${ }^{4}$ and A Rahman ${ }^{5}$
}

\begin{abstract}
An experiment was conducted at the research farm of Bangabandhu Sheikh Mujibur Rahman Agricultural University (BSMRAU) during May to September 2008 to investigate the effect of alley widths of Gliricidia sepium and different nitrogen levels on yield of Aus rice (BR24). The experiment was laid out in a split-plot design with three replications. Three alley widths $3.0,4.5$, and $6.0 \mathrm{~m}$ and a control, without tree were compared under five $\mathrm{N}$ doses $0,18.75,37.5,56.25$ and $75 \mathrm{~kg} \mathrm{ha}^{-1}$. G. Sepium species gave the highest $\left(20.24 \mathrm{tha}^{-1}\right)$ pruned materials from closer alley width $(3 \mathrm{~m})$. The highest grain yield (3.54 tha-1) of rice was obtained at $75 \mathrm{~kg} \mathrm{~N}$ from urea and pruned materials (PM) in $4.5 \mathrm{~m}$ alley width. The study suggests that $G$. sepium can contribute to increase rice yield and increase $\mathrm{N}$ use efficiency.
\end{abstract}

Key words: Agroforestry systems, alley, nitrogen levels, yield.

\section{INTRODUCTION}

Alley cropping is an agroforestry practice in which perennial preferably leguminous trees or shrubs are grown simultaneously with an arable crop. Due to intensive cultivation soil fertility is reducing rapidly, consequently reducing the yield of crop. Intensive cultivation associated with the application of various chemical fertilizers and pesticides rapidly degrading the natural soil ecosystem, polluting water resources and environment as well (Hossain and Kashem, 1997). As a result, the organic matter content of soil is depleting rapidly. Out of many reason it is one of the important cause for reducing organic matter content of soil. Alley cropping is an ideal technology for sustainable crop production within agricultural cropping systems through maximum utilization of land resources. The important benefit of alley cropping is the addition of large amounts of organic materials from the prunings as mulch or green manure that increase soil organic carbon (Kang et al., 1985; Kang and Ghuman 1991). Fast growing leguminous tree or shrub species like Gliricidia sepium are preferred as alley crop because it recycles nutrients, contribute biological nitrogen fixation and provide fuel, fodder and timber (Kang et al., 1985). A wider spacing minimizes the tree-crop competition and a narrower spacing maximizes the weed control (Vanlauwe et al., 1998) as well as tree-crop competition. So, investigation of the benefits of this system in terms of nitrogen saving, crop performance as well as different alley widths in the flatland agro-ecosystem of Bangladesh would be of immense value to the farmers as well as scientists.

Nitrogen (N) level and organic matter contents in the soil of Bangladesh are very poor. Use of $\mathrm{N}$ fertilizer can be reduced through this system as $\mathrm{N}$ is added to the soil through leaf or root decomposition as well as $\mathrm{N}$ is fixed through the roots of the legumes. There are extensive literatures about the benefit of alley cropping but information on rice based

1Senior Scientific Officer, Regional Station, BRRI, Satkhira.

2Professor, Department of Agroforestry and Environment, BSMRAU,Gazipur.

${ }^{3}$ Former Director General, BRRI, Gazipur.

${ }^{4}$ Coordinator for Advanced Studies and Research, BRRI, Gazipur

${ }^{5}$ Associate Professor, Department of Agroforestry and Environment, BSMRAU, Gazipur

Corresponding author's email:satyen1981@gmail.com 
systems are not enough. Since, such type of studies are limited in the flatland ecosystem of Bangladesh, it is needed to conduct a study to explore the potentiality of this system at varying alley widths on the productivity of crops like rice. Therefore, a study was undertaken to evaluate the performance of Gliricidia sepium as well as to assess the Nfertilizer saving and the productivity of rice grown at varying alley width of Gliricidia sepium, under different N-levels.

\section{MATERIALS AND METHODS}

The experiment was conducted at the Bangabandhu Sheikh Mujibur Rahman Agricultural University (BSMRAU) research farm, Gazipur during the period from May 2008 to September 2008 under rainfed condition. The Gliricidia sepium seedlings were transplanted in line at $50 \mathrm{~cm}$ apart in the experimental field in September, 2005 and adequate management practices were done to establish the seedling. Alley widths were 3.0, 4.5 and $6.0 \mathrm{~m}$. Every alley was divided into 15 unit plots comprising three replications and five levels of nitrogen. The unit plot length was $5 \mathrm{~m}$. So, total area of a unit plot was $3 \times 5,4.5 \times 5$ and $6 \mathrm{~m} \times 5 \mathrm{~m}$ for alley of 3.0, 4.5 and $6.0 \mathrm{~m}$, respectively. The five sub plots having different nitrogen levels were $\mathrm{N}_{\mathrm{o}}$ (zero dose of $\left.\mathrm{N}\right)+$ Pruned materials $(\mathrm{PM}), \mathrm{N}_{25}(25 \%$ of recommended $\mathrm{N}$ dose $)+\mathrm{PM}$, $\mathrm{N}_{50}(50 \%$ of recommended $\mathrm{N}$ dose $)+\mathrm{PM}, \mathrm{N}_{75}(75 \%$ of recommended $\mathrm{N}$ dose $)+\mathrm{PM}, \mathrm{N}_{100}$ (100\% of recommended $\mathrm{N}$ dose) + PM. Control plots (15 in number with 3 replications) received five $\mathrm{N}$ levels $0,18.75,37.5,56.25$ and $75 \mathrm{~kg} \mathrm{ha}^{-1}$ but no PM was used in those plots. The control plots were kept to compare the results with crop yields under alley cropping system. Urea was used as the source of different nitrogen doses. The experiment was laid out in a split-plot design, each treatment had three replications. Alley widths of Gliricidia sepium were in main plots, and five nitrogen levels were distributed to sub-plot under each alley widths. Seeds were sown in line sowing in the assigned plots of alleys as well as in the control plots from 17 to18 May 2008. The seeds were sown in line sowing at the rate of $50 \mathrm{~kg}$ per hectare at $25 \mathrm{~cm}$ line to line distance. Effective grain yield = Yield of 01 linear meter occupied by tree+ Grain yield of alley cropping systems. The data relating to yield and yield contributing characters of rice and tree performance were subjected to analysis of variation (ANOVA) with the help of computer "MSTATC" program. The means were compared by using DMRT.

\section{RESULTS AND DISCUSSION}

\section{Performance of tree species at different alley widths}

Three was no effect of alley width of Gliricidia sepium on plant height, node diameter, base diameter branching habit and weight of pruning materials per tree. But there was an effect of alley width of Gliricidia sepium on producing pruned materials per hectare. The total fresh pruned materials obtained from $3.0 \mathrm{~m}$ alley width was the highest $\left(20.24 \mathrm{t} \mathrm{ha}^{-1}\right)$ among the alley widths, while $4.5 \mathrm{~m}$ and $6.0 \mathrm{~m}$ alley widths produced, $13.14 \mathrm{t} \mathrm{ha}^{-1}$ and $9.92 \mathrm{t} \mathrm{ha}^{-1}$ pruned materials, respectively. It revealed that closer $(3.0 \mathrm{~m})$ alley width produced the highest $(20.24$ $\left.t \mathrm{ha}^{-1}\right)$ mean total fresh pruned materials while the lowest $\left(9.92 \mathrm{t} \mathrm{ha}^{-1}\right)$ mean total fresh pruned materials was observed in wider $(6.0 \mathrm{~m})$ alley width.(Table 1.). 
Table 1. Fresh pruned materials produced from Gliricidia sepium species and added to the soil during rice growing period in alley cropping systems during Aus season, 2008

\begin{tabular}{|l|l|l|l|l|l|l|}
\hline \multirow{3}{*}{$\begin{array}{c}\text { Alley Width } \\
(\mathrm{m})\end{array}$} & \multicolumn{6}{|c|}{ Pruned materials produced and added to the soil } \\
\cline { 2 - 8 } & \multicolumn{5}{|c|}{ Fresh weight } \\
\cline { 2 - 8 } & Leaf & Branch & Total & Leaf & Branch & Total \\
\hline 3.0 & 1595.87 & 1101.30 & 2697.17 & $11.98 \mathrm{a}$ & $8.26 \mathrm{a}$ & $20.24 \mathrm{a}$ \\
\hline 4.5 & 1535.45 & 1065.70 & 2601.15 & $7.76 \mathrm{~b}$ & $5.38 \mathrm{~b}$ & $13.14 \mathrm{~b}$ \\
\hline 6.0 & 1528.39 & 1061.21 & 2589.60 & $5.86 \mathrm{c}$ & $4.06 \mathrm{c}$ & $9.92 \mathrm{c}$ \\
\hline $\mathrm{CV}(\%)$ & 1.76 & 3.62 & 2.05 & 8.90 & 8.30 & 7.59 \\
\hline
\end{tabular}

In column, means followed by a common small letter are not significantly different at the 5\% level by DMRT

\section{Performance of Aus rice}

\section{Number of Panicle}

Number of panicle per square meter of rice was not affected significantly by different alley width (Table 2.) but number of panicle per square meter of rice was increased significantly with comparatively higher $\mathrm{N}$ levels. The highest number of panicle per square meter (227.00) was noted in $100 \% \mathrm{~N}$ level, which was statistically similar with $75 \% \mathrm{~N}$ level. The lowest number of panicle per square meter (161.65) was recorded in $0 \% \mathrm{~N}$ level, which was significantly different with $25 \% \mathrm{~N}$ level.

The combined effect of alley width and $\mathrm{N}$ levels in respect of number of panicle per square meter was significantly different. However, the highest (231.60) number of panicle per square meter was noted in $100 \% \mathrm{~N}$ level at $4.5 \mathrm{~m}$ alley width. This was statistically similar with $75 \%$ and $50 \% \mathrm{~N}$ levels irrespective of alley widths. The lowest (122.28) number of panicle was produced at control plot. This was significantly different with $0 \% \mathrm{~N}$ level of all alley widths. The increased number of panicle per square meter in different alley width compared with control was probably because of adding pruning materials. These findings were coinciding with the results of Nayak et al., (1979) as well as Adhikary (1990).

Table 2. Effect of $\mathrm{N}$ levels and alley widths on panicle $\mathrm{m}^{-2}$ and grain panicle-1 of Aus rice, 2008

\begin{tabular}{|c|c|c|c|c|c|c|c|c|}
\hline \multirow{3}{*}{$\begin{array}{l}\text { Nitrogen } \\
\text { levels\% }\end{array}$} & \multicolumn{8}{|c|}{ Alley width (m) } \\
\hline & 3 & 4.5 & 6 & \multirow[b]{2}{*}{ Mean } & 3 & 4.5 & 6 & \multirow[b]{2}{*}{ Mean } \\
\hline & $\begin{array}{l}\text { Panicle } \\
\left(\mathrm{m}^{-2}\right)\end{array}$ & $\begin{array}{l}\text { Panicle } \\
\left(\mathrm{m}^{-2}\right)\end{array}$ & $\begin{array}{l}\text { Panicle } \\
\left(\mathrm{m}^{-2}\right)\end{array}$ & & $\begin{array}{l}\text { Grain } \\
\left(\text { panicle }^{-1}\right)\end{array}$ & $\begin{array}{l}\text { Grain } \\
\left(\text { panicle }^{-1}\right)\end{array}$ & $\begin{array}{l}\text { Grain } \\
\left(\text { panicle }^{-1}\right)\end{array}$ & \\
\hline 0 & $155.2 \mathrm{~g}$ & $161.56 \mathrm{fg}$ & $168.20 \mathrm{efg}$ & 161.65 & $62.90 \mathrm{gh}$ & $67.92 \mathrm{fg}$ & $66.71 \mathrm{~g}$ & 65.84 \\
\hline 25 & $184.7 \mathrm{def}$ & 190.44 cde & $196.92 \mathrm{bcd}$ & 190.69 & $69.62 \mathrm{fg}$ & $73.33 \mathrm{ef}$ & $71.45 \mathrm{fg}$ & 71.47 \\
\hline 50 & $201.88 \mathrm{abc}$ & $205.48 \mathrm{abc}$ & $213.44 \mathrm{abc}$ & 206.93 & $80.94 \mathrm{~cd}$ & $82.18 \mathrm{bc}$ & $82.61 b c$ & 81.91 \\
\hline 75 & $214.32 \mathrm{abc}$ & $233.68 \mathrm{ab}$ & $224.40 \mathrm{ab}$ & 224.13 & $88.29 \mathrm{ab}$ & $86.26 \mathrm{abc}$ & $85.92 \mathrm{abc}$ & 86.82 \\
\hline 100 & $223.88 \mathrm{ab}$ & $225.52 \mathrm{ab}$ & $231.60 \mathrm{a}$ & 227.00 & $89.41 \mathrm{a}$ & $92.47 \mathrm{a}$ & $90.16 \mathrm{a}$ & 90.68 \\
\hline control & $122.28 \mathrm{~h}$ & $122.28 \mathrm{~h}$ & $122.28 \mathrm{~h}$ & 122.28 & $60.14 \mathrm{~h}$ & $60.14 \mathrm{~h}$ & $60.14 \mathrm{~h}$ & 60.14 \\
\hline Mean & 183.71 & 189.83 & 193.41 & 188.98 & 75.22 & 78.21 & 76.17 & 76.53 \\
\hline CV (\%) & 6.69 & 6.69 & 6.69 & - & 3.98 & 3.98 & 3.98 & - \\
\hline
\end{tabular}

In column, means followed by a common small letter are not significantly different at the $5 \%$ level by DMRT

\section{Grain per panicle}

Number of grain per panicle of rice was not significantly influenced by alley widths (Table 2 ), however grain number per panicle was increased significantly by the application of 
different $\mathrm{N}$ levels. Among the $\mathrm{N}$ levels, the highest number grain per panicle (90.65) was found in $100 \% \mathrm{~N}$ levels which was significantly different from $75 \% \mathrm{~N}$ level. The lowest grain number per panicle (65.84) was produced by $0 \% \mathrm{~N}$ level that was identical to $25 \% \mathrm{~N}$ level (Table 2).

The interaction effect of alley width and $\mathrm{N}$ levels in respect of grain number per panicle differed significantly (Table 2). Result showed that the highest (92.47) grain number per panicle was obtained from $100 \% \mathrm{~N}$ level at $4.5 \mathrm{~m}$ alley width. This was statistically similar to $75 \% \mathrm{~N}$ level irrespective of alley widths. The lowest grain number per panicle (60.14) was found in control plot. Grain number per panicle of $50 \% \mathrm{~N}$ level was statistically similar to $75 \% \mathrm{~N}$ level irrespective of 3 alley widths but significantly different from $25 \% \mathrm{~N}$ level of all alley widths. Pruned materials (PM) and $\mathrm{N}$ level has positive effect on increasing grain number per panicle. Hossain et al. (1997) found higher grain per panicle with higher $\mathrm{N}$ dose plus N supplied from organic sources.

\section{Grain yield}

Grain yield of rice was not significantly affected by alley width (Table 3) but it was was influenced with $\mathrm{N}$ levels. Among the $\mathrm{N}$ levels the highest yield of rice ( 3.47 tha $\left.^{-1}\right)$ was found where full dose of $\mathrm{N}$ was applied. This yield level was statistically identical to $75 \% \mathrm{~N}$ level (3.29 $\mathrm{t} \mathrm{h} \mathrm{a}^{-1}$ ) but significantly different from the other treatments. Significantly the lowest grain yield (1.48 $\mathrm{t} \mathrm{ha}^{-1}$ ) was recorded at control plot (Table 3).

The combined effect of alley width and $\mathrm{N}$ levels in respect of grain yield was significantly different (Table 3). Result revealed that the highest yield of rice (3.54 $\left.\mathrm{t} \mathrm{ha}^{-1}\right)$ was obtained from $100 \% \mathrm{~N}$ level at $4.5 \mathrm{~m}$ alley width which was statistically similar to $75 \% \mathrm{~N}$ level irrespective of alley widths. Pruning materials yielded $0.50 \mathrm{t} \mathrm{ha}^{-1}$ more yield which was equivalent to $37 \%$ more over control. The higher grain yield of rice with higher $\mathrm{N}$ levels was mainly due to higher panicle per square meter and also due to combined contribution of other yield components. Szott et al. (1987) also found that the higher grain yield with higher $\mathrm{N}$ dose.

Table 3. Effect of $\mathrm{N}$ levels and alley widths on grain yield and effective grain yield of Aus rice, 2008

\begin{tabular}{|c|c|c|c|c|c|c|c|c|}
\hline \multirow{3}{*}{$\begin{array}{l}\text { Nitrogen } \\
\text { levels\% }\end{array}$} & \multicolumn{8}{|c|}{ Alley width ( m) } \\
\hline & 3 & 4.5 & 6 & \multirow[b]{2}{*}{$\begin{array}{l}\text { Mean } \\
\left(\mathrm{t} \mathrm{ha}^{-1}\right)\end{array}$} & 3 & 4.5 & 6 & \multirow[b]{2}{*}{$\begin{array}{l}\text { Mean } \\
\left(\mathrm{t} \text { ha-1 }^{-1}\right)\end{array}$} \\
\hline & $\begin{array}{l}\text { Grain } \\
\text { yield } \\
\left(\mathrm{t} \mathrm{ha}^{-1}\right)\end{array}$ & $\begin{array}{l}\text { Grain } \\
\text { yield } \\
\left(\mathrm{t} \mathrm{ha}^{-1}\right)\end{array}$ & $\begin{array}{l}\text { Grain } \\
\text { yield } \\
\left(\mathrm{t} \mathrm{ha}^{-1}\right)\end{array}$ & & $\begin{array}{l}\text { Effective } \\
\text { grain yield } \\
\left(\mathrm{t} \mathrm{ha}^{-1}\right)\end{array}$ & $\begin{array}{l}\text { Effective } \\
\text { grain yield } \\
\left(\mathrm{t} \mathrm{ha}^{-1}\right)\end{array}$ & $\begin{array}{l}\text { Effective } \\
\text { grain yield } \\
\left(\mathrm{t} \mathrm{ha}^{-1}\right)\end{array}$ & \\
\hline 0 & $1.96 \mathrm{f}$ & $2.00 \mathrm{f}$ & $1.99 \mathrm{f}$ & 1.98 & $2.45 \mathrm{ij}$ & $2.23 \mathrm{k}$ & $2.16 \mathrm{k}$ & 2.28 \\
\hline 25 & $2.42 \mathrm{e}$ & $2.46 \mathrm{dc}$ & $2.44 \mathrm{de}$ & 2.44 & $2.82 \mathrm{fgh}$ & $2.67 \mathrm{hi}$ & $2.65 \mathrm{hi}$ & 2.71 \\
\hline 50 & $2.77 \mathrm{c}$ & $2.87 \mathrm{c}$ & $2.78 \mathrm{c}$ & 2.81 & $3.29 \mathrm{~cd}$ & $3.04 \mathrm{de}$ & $2.94 \mathrm{fg}$ & 3.09 \\
\hline 75 & $3.29 \mathrm{ab}$ & $3.30 \mathrm{ab}$ & $3.27 \mathrm{ab}$ & 3.29 & $3.70 \mathrm{ab}$ & $3.56 b c$ & $3.46 \mathrm{bc}$ & 3.57 \\
\hline 100 & $3.42 \mathrm{a}$ & $3.54 \mathrm{a}$ & $3.45 \mathrm{a}$ & 3.47 & $3.92 \mathrm{a}$ & $3.84 \mathrm{ab}$ & $3.71 \mathrm{ab}$ & 3.82 \\
\hline control & $1.48 \mathrm{~h}$ & $1.48 \mathrm{~h}$ & $1.48 \mathrm{~h}$ & 1048 & $1.48 \mathrm{~h}$ & $1.48 \mathrm{~h}$ & $1.48 \mathrm{~h}$ & 1.48 \\
\hline Mean & 2.56 & 2.61 & 2.57 & 2.58 & 2.94 & 2.80 & 2.73 & 2.82 \\
\hline CV (\%) & 1.81 & 1.81 & 1.81 & - & 1.81 & 1.81 & 1.81 & - \\
\hline
\end{tabular}

In column, means followed by a common small letter are not significantly different at the $5 \%$ level by DMR 


\section{Effective grain yield}

Effective grain yield was measured by counting grain yield, which can be produced from the area that occupied by tree during the experiment. Effective grain yield was more by 16, 11 and $8 \%$ for $3 \mathrm{~m}, 4.5 \mathrm{~m}$ and $6 \mathrm{~m}$ alley width, respectively than the grain yield in alley cropping system. The effect of alley width of G. sepium species was significant in producing effective grain yield (Table 3 ) but not within $4.5 \mathrm{~m}$ and $6 \mathrm{~m}$ alley width. In this situation, among the alley width the highest $\left(2.94 \mathrm{t} \mathrm{ha}^{-1}\right)$ and the lowest effective grain yield $(2.73 \mathrm{t}$ ha1) were noted in $3 \mathrm{~m}$ and $6 \mathrm{~m}$ alley width, respectively. Effective grain yield was increased with the increase $\mathrm{N}$ levels, where the highest effective grain yield ( $\left.3.82 \mathrm{tha}^{-1}\right)$ was recorded at $100 \% \mathrm{~N}$ level. This is statistically identical to $75 \% \mathrm{~N}$ level $\left(3.57 \mathrm{t} \mathrm{ha}^{-1}\right)$. On the other hand significantly the lowest effective grain yield $\left(2.28 \mathrm{t} \mathrm{ha}^{-1}\right)$ was observed in $0 \% \mathrm{~N}$ level (Table 3). In case of interaction effect, the highest effective grain yield (3.92 $\mathrm{t}$ ha $\left.{ }^{-1}\right)$ was found in $3 \mathrm{~m}$ alley width at $100 \% \mathrm{~N}$ level. This was statistically similar to $75 \% \mathrm{~N}$ level irrespective of alley widths. Significantly the lowest effective grain yield $\left(1.48 \mathrm{t}\right.$ ha $\left.{ }^{-1}\right)$ was found in control plot (Table 4). Effective grain yield was comparatively higher in $3 \mathrm{~m}$ alley width because it occupied more land than other two alley widths. Gonzal and Raros (1987) found out that the Gliricidia mulch increase upland rice by $15-28 \%$ yield. This result is in agreement with the findings of Sing and verma (1999), Ghos and Sharma (1999), Babu and Reddy (2000) who also found the similar results.

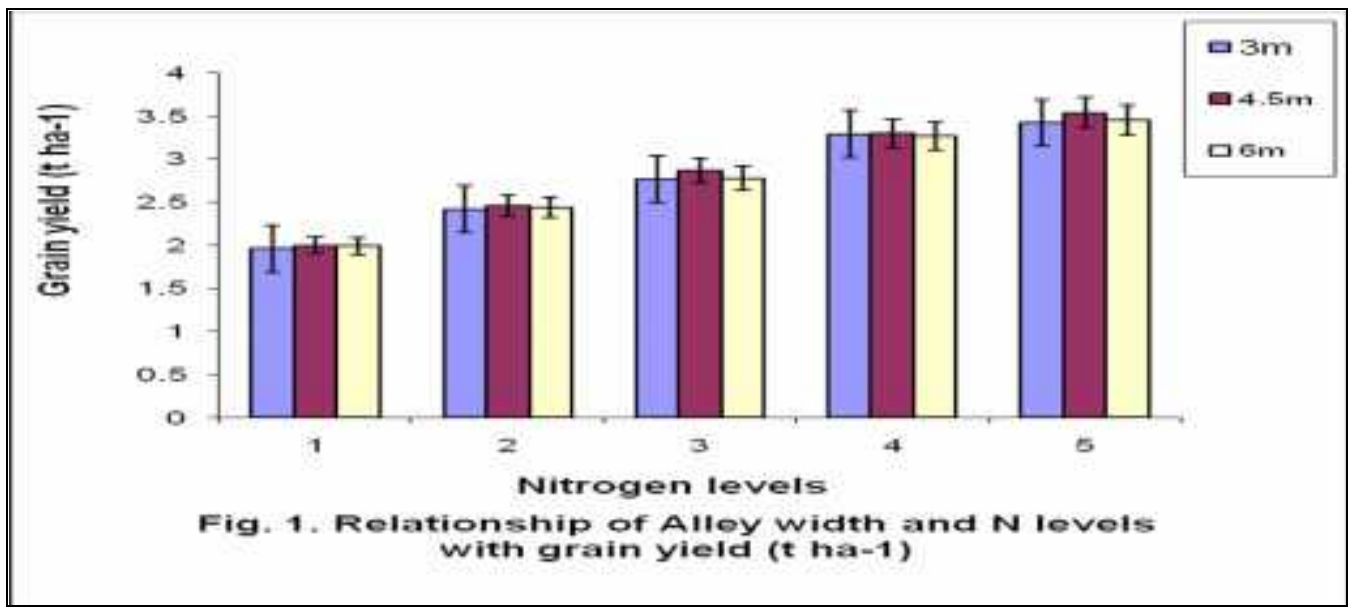

\section{Plant height}

There was no significant effect of alley width on plant height. In contrast, plant height of rice was increased with $\mathrm{N}$ levels, where significantly the tallest $(106.07 \mathrm{~cm})$ and the shortest $(76.63 \mathrm{~cm})$ plants were found at $100 \%$ and $0 \% \mathrm{~N}$ levels, respectively. In case of interaction effect, the tallest plant $(108.60 \mathrm{~cm})$ was found in $3 \mathrm{~m}$ alley width at $100 \% \mathrm{~N}$ level which was statistically similar to $75 \% \mathrm{~N}$ level irrespective of alley widths. Significantly, the lowest plant height (57.00) was found in control plot. Plant height of 50\% N level was statistically similar to $25 \% \mathrm{~N}$ level of $3 \mathrm{~m}$ alley widths. Plant height of $3 \mathrm{~m}$ alley width was the highest because of shade provided by tree species. Similar trend of plant height of red amaranth under guava and drumstick trees alley cropping reported by Ali (1999) and Rahman (2001).

\section{Straw yield}

The effect of alley width was not significant in producing straw yield (Table 4). Straw yield responded favorably to applied $\mathrm{N}$ levels. However, the highest straw yield was observed in $100 \% \mathrm{~N}$ level. This was statistically identical to $75 \% \mathrm{~N}$ levels. The interaction effect of alley 
width and $\mathrm{N}$ levels in respect of straw yield was significantly different (Table 4). Straw yield level showed that the highest straw yield $\left(3.98 \mathrm{t} \mathrm{ha}^{-1}\right)$ was obtained from $100 \% \mathrm{~N}$ level at 4.5 $\mathrm{m}$ alley width. This was statistically similar to $75 \% \mathrm{~N}$ level irrespective of alley widths. Significantly the lowest straw yield was found in control plot $\left(1.72 \mathrm{t} \mathrm{ha}^{-1}\right)$. Straw yield of 50\% $\mathrm{N}$ level was statistically similar with $75 \% \mathrm{~N}$ level of different alley widths but significantly different from $25 \% \mathrm{~N}$ level of all alley widths. Straw yield was found co-related with plant height that was increased with the increase of $N$ levels. Duhan et al. (1989) reported that chemical sources of nutrient have significant effect on yield of rice straw yield.

Table 4. Effect of $N$ levels and alley widths on plant height $(\mathrm{cm})$ and straw yield (t ha-1) of Aus rice-2008

\begin{tabular}{|c|c|c|c|c|c|c|c|c|}
\hline \multirow{3}{*}{$\begin{array}{l}\text { Nitrogen } \\
\text { levels } \%\end{array}$} & \multicolumn{8}{|c|}{ Alley width ( $\mathrm{m})$} \\
\hline & 3 & 4.5 & 6 & \multirow[b]{2}{*}{$\begin{array}{l}\text { Mean } \\
(\mathrm{cm})\end{array}$} & 3 & 4.5 & 6 & \multirow[b]{2}{*}{$\begin{array}{l}\text { Mean } \\
\left(\mathrm{t} \mathrm{ha}^{-1}\right)\end{array}$} \\
\hline & $\begin{array}{l}\text { Plant } \\
\text { height } \\
(\mathrm{cm})\end{array}$ & $\begin{array}{l}\text { Plant } \\
\text { height } \\
(\mathrm{cm})\end{array}$ & $\begin{array}{l}\text { Plant } \\
\text { height } \\
(\mathrm{cm})\end{array}$ & & $\begin{array}{l}\text { Straw } \\
\text { yield } \\
\left(\mathrm{t} \mathrm{ha}^{-1}\right)\end{array}$ & $\begin{array}{l}\text { Straw yield } \\
\left(\mathrm{t} \mathrm{ha}^{-1}\right)\end{array}$ & $\begin{array}{l}\text { Straw yield } \\
\left(\mathrm{t} \mathrm{ha}^{-1}\right)\end{array}$ & \\
\hline 0 & $76.35 \mathrm{~g}$ & $75.99 \mathrm{~g}$ & $77.55 \mathrm{fg}$ & 76.63 & $2.01 \mathrm{f}$ & $2.09 \mathrm{f}$ & $2.02 \mathrm{f}$ & 2.04 \\
\hline 25 & $82.69 \mathrm{efg}$ & $85.50 \mathrm{def}$ & $85.01 \mathrm{def}$ & 84.40 & $2.69 \mathrm{e}$ & $2.73 \mathrm{e}$ & $2.71 \mathrm{e}$ & 2.71 \\
\hline 50 & $88.60 \mathrm{de}$ & $89.26 \mathrm{de}$ & $90.42 \mathrm{de}$ & 89.43 & $3.20 \mathrm{bc}$ & $3.04 \mathrm{~cd}$ & $3.19 \mathrm{bc}$ & 3.14 \\
\hline 75 & $103.16 \mathrm{ab}$ & 99.71 bc & 99.38 bc & 100.75 & $3.32 \mathrm{ab}$ & $3.65 \mathrm{ab}$ & $3.66 \mathrm{ab}$ & 3.54 \\
\hline 100 & $108.60 \mathrm{a}$ & $105.60 \mathrm{ab}$ & $104.00 \mathrm{ab}$ & 106.07 & $3.56 \mathrm{a}$ & $3.98 \mathrm{a}$ & $3.96 \mathrm{a}$ & 3.83 \\
\hline Control & $57.00 \mathrm{~h}$ & $57.00 \mathrm{~h}$ & $57.00 \mathrm{~h}$ & 57.00 & $1.72 \mathrm{~g}$ & $1.72 \mathrm{~g}$ & $1.72 \mathrm{~g}$ & 1.72 \\
\hline Mean & 86.07 & 85.51 & 85.55 & 85.71 & 2.75 & 2.87 & 2.88 & 2.83 \\
\hline CV (\%) & 2.66 & 2.66 & 2.66 & - & 7.46 & 7.46 & 7.46 & - \\
\hline
\end{tabular}

In column, means followed by a common small letter are not significantly different at the $5 \%$ level by DMRT

\section{CONCLUSION}

The highest amount of fresh pruned materials was produced and added to the soil from 3.0 $\mathrm{m}$ alley width, which was followed by $4.5 \mathrm{~m}$ and $6.0 \mathrm{~m}$ alley width, respectively. Twenty five percent nitrogen cost can be saved by using pruned materials for showing maximum potentiality of rice yield. However, $\mathrm{N}_{0}+\mathrm{PM}$ treatment yielded $37 \%$ more yield over control.

\section{REFERRENCES}

Adhikary, N P. 1990. Physio-morphological response of upland rice. A Ph. D. dissertation UPLB, Los Banos, Laguna, Philippines.

Ali, M A. 1999. Performance of red amaranth and lady's finger growth at different orientation and distances under guava and drumstick trees. MS Thesis, BSMRAU,Gazipur.

Babu, B T R and V C Reddy. 2000. Effect of nutrient sources on growth and yield of direct seeded rice (Oryza sativa. L.). Crop Res. Hioar. 19(2):189-193

Duhan, B, B T Kang, and D U U Okali. 1989. Effect of pruning intensities of three woody leguminous species grown in alley cropping with maize and cowpea on an Alfisol. Agroforestry Systems 6:19-35.

Ghos, A and A R Sharma.1999. Effect of combined use of organic matter and nitrogen fertilizer of the performance of rice under flood prone low land conditions J. Agril .Sci. 132(4):461-465.

Gonzal and Raros. 1987. Effect of Gliricidia mulch on upland rice in central America. Agroforestry Systems, 5:26-33. 
Hossain, S M A. and M A Kashem. 1997. Management combat declining soil fertility in Bangladesh. Keynote paper. Proceeding of the $6^{\text {th }}$ Biennial Conference of the Bangladesh Society of Agronomy. Held on 29 July 1997. pp. 22-39.

Kang, B T and B S Ghuman.1991. Development of Conservation Farming on Hillslopes. Soil and Water Conservation Society, Ankeny, Iowa, USA, pp. 172-184.

Kang, B T, G F Wilson and T L Lawson. 1985. Alley cropping: a stable alternative to shifting cultivation. IITA, Ibadan, Nigeria.

Nayak, S K, P S S Murty and K S Murty.1979. Photosynthesis and translocation in rice during ripening as influenced by different light intensities. J. Nuclear gric.Biol.8 (1):23-15.

Rahman, M A 2001. Effect of alley cropping with different nitrogen levels on crop productivityand soil properties in upland ecosystem. MS thesis, Department of Agroforestry and Environment. BSMRAU, Gazipur, Bangladesh.

Singh, N B and K K verma. (1999). Integrated nutrient management in rice - wheat crop sequences, oryza.36 (2):171-172.

Szott, L T 1987. Improving the productivity of shifting cultivation in the Amazon basin of Peru through the use of leguminous vegetation. PhD thesis, North Carolina State University, Raleigh, USA.

Vanlauwe, B, N Sanginga, and R Merckx. 1998. Recovery of leucaena and dactyladenia residue nitrogen-15 in alley cropping systems. Soil Science Society of American Journal. 62: 454-460. 